\title{
Inclusive education in Spain: How do skills, resources, and supports affect regular education teachers' perceptions of inclusion?
}

\author{
Esther Chiner-Sanz ${ }^{*}$ and M. Cristina Cardona-Moltó \\ Faculty of Education, University of Alicante, Alicante, Spain
}

\begin{abstract}
This study examined regular education teachers' perceptions of inclusion in elementary and secondary schools in Spain and how these perceptions may differ depending on teaching experience, skills, and the availability of resources and supports. Stratified random sampling procedures were used to draw a representative sample of 336 general education teachers (68 kindergarten, 133 elementary, and 135 secondary teachers) from the province of Alicante. Results indicated acceptance of the principles of inclusion, although teacher skills, time, material resources, and personal supports for inclusion were deemed insufficient. Kindergarten and elementary teachers showed more positive perceptions of inclusion than secondary education teachers. So did teachers with more personal supports and material resources compared to those with less supports and resources. Results are discussed in terms of its implications for practice in order to promote more inclusive classrooms in Spain.
\end{abstract}

Keywords: inclusive education; teachers' perception; special educational needs; regular education teachers; Spain

\footnotetext{
*Corresponding author. Email: esther.chiner@ua.es
} 


\section{Introduction}

Inclusive education is a concept that allows students with diverse needs to be placed and receive instruction in regular schools and classrooms. It can be understood 'as the presence (access to education and school attendance), participation (quality of the learning experience from the learners' perspective) and achievement (learning processes and outcomes across the curriculum) of all learners in mainstream schools' (EADSNE $2011,9)$. This educational trend has been encouraged internationally as a positive means of enhancing students' overall development and functioning and basically means bringing special services, when necessary, into the classrooms to allow students with disabilities and/or diverse educational needs to be members of the same community as other children (Evans 1998). In Spain, although the inclusion movement (LISMI 1982; LOE 2006; LOGSE 1990) has contributed to reinforce general education teachers' basic responsibility for increasing student participation, little is known about teachers' acceptability of this practice particularly when taking into account the specific conditions under which inclusion is currently being implemented.

As in many other countries, Spain subscribed to the principles of inclusion early in the nineties and since then has carried out several educational reforms in order to transform an educational system until then selective into a more comprehensive one. Preliminary changes arrived early in the seventies with PL 14/1970, General Law of Education and Financing of the Educational Reform (LGE 1970), and the Spanish Constitution of 1978. PL 14/1970 meant the recognition of special education as a part of the educational system, although students with special educational needs (SEN) were still attended in segregated settings (special schools). Students with disabilities had to wait more than ten years until the publication of PL 13/1982, Law of Social Integration of Disabled People (LISMI 1982) to see their rights fully recognised. LISMI promoted the integration of people with disabilities in all the spheres of their lives (society, school, and work). For students with SEN also meant the beginning of a process of integration into regular schools through an eight-year experimental programme. Along with this law, the educational reform carried out in the nineties with PL 1/1990, Organic Law of General Arrangement of the Educational System (LOGSE 1990) definitely contributed to change the way students with disabilities were educated. During the nineties, significant progress was made: the new concept of 'special educational needs' 
was introduced, special education became a part of the general education system with a common curriculum for all students, and curriculum adaptations and educational differentiation were on the basis of attending students' educational needs. The following reforms (PL 10/2002 and PL 2/2006) have only introduced minor changes regarding the education of SEN students and basically refer to terminology. PL 10/2002, Organic Law of Quality of Education (LOCE 2002), introduced the generic term 'specific educational needs' to refer to foreign students, gifted students, and those students that need compensatory education; and PL 2/2006, Organic Law of Education (LOE 2006), incorporated the terms of inclusion and equity advocated in international declarations such as the Salamanca Statement and Framework for Action on Special Needs Education (UNESCO 1994).

The current educational system, is regulated by PL 2/2006 and comprises two free compulsory levels: Elementary Education (6-12) and Secondary Education (12-16), but children from 3 to 6 years old have the option of attending pre-school (Kindergarten) level which is non-compulsory and free for all students. Post-secondary education is composed of two-year high school (Bachillerato) or vocational studies (1819). Kindergarten, elementary, and secondary school children with SEN are included in regular classrooms. High school and university level are working on inclusive practice but still there is much to do. Spain has a decentralized system of teacher education and certification. Each Autonomous Community and university is responsible for initial certification and credentialing of its teachers. Prospective teachers have to complete a four-year undergraduate program for initial certification in three majors (kindergarten and elementary education at graduate level, and secondary education at master level). A typical undergraduate teacher education program (e.g., Maestro: Elementary Education) consists of 240 credits composed of general studies (60 credit core courses), studies on teaching subject area (102 credit courses), practicum (48 credits), and electives (24 credits) plus a 6 credit final project. Emphasis is made on diversity but there are only 24 credit courses (12 credit core courses and 12 electives) on students with SEN. A graduate teacher program (e.g., Profesor: Secondary Education) consists of 60 more credits $(14+30+16$ credits) on general studies, studies on specific teaching subject area, and practicum, respectively, with only a maximum of 6 credits dealing with the study of diversity.

Spain is considered to have one of the most inclusive educational systems in Europe with less than $0.4 \%$ of SEN students being educated in separate special schools 
(EADSNE 2003, 2011; Hegarty 1998). This percentage is very low compared to the $4 \%$ of Belgium, Denmark, Germany, or Switzerland (EADSNE 2011). Of the 2.2\% of students identified as having special needs in Spain, approximately five are enrolled in separate schools/self-contained classrooms, while $17 \%$ attend regular classrooms. The greater proportion of mainstreamed students can be found in elementary school $(58.4 \%)$ followed by secondary school (35.2\%) and post-secondary school (6.4\%) (Cardona 2009). In addition, public schools serve $73 \%$ of the students with SEN and have the highest proportion of mainstreamed students ( 8 of 10 students). However, despite the significant advances in legislation and in the fulfilment of student rights there is still much to be done. According to Echeita and Verdugo (2004): a medical perspective in special education is still alive, which makes professionals understand special educational needs as a deficit more than an interaction between the individual and the context; responsibility still falls on specialists (e.g., special education teachers, school psychologists, speech therapists) instead of being a share responsibility; and lack of adequate training and supports, as well as some resistance to change is still present.

In this context, teachers' perceptions and attitudes towards inclusion have been, indeed, one of the major concerns in educational research recently in this country. International literature shows that, overall, teachers agree with the general concept of inclusion, although their attitudes and perceptions are less positive when they have to include SEN students into their classrooms. These were the conclusions of a review of the literature carried out by Scruggs and Mastropieri (1996) from 28 studies (19581995) about North American and Australian teachers' attitudes towards integration and inclusion. The authors reported that, despite the fact that two thirds of the teachers $(n=$ $10,560)$ supported the philosophy of inclusion, only a few were actually willing to include SEN students in their own classrooms. Avramidis and Norwich (2002), in a later review that included studies from other countries, mainly European countries, agreed with Scruggs and Mastropieri's conclusions and found that teacher acceptance of inclusion was not total. The ambivalence between teacher thinking and action seems to be related to some factors that may lessen their willingness to having students with special educational needs in their classrooms. Most teachers report lack of training, time, resources and supports when they try to address their students' learning needs. Avramidis, Bayliss, and Burden (2000) found that teachers requested more pre-service and in-service training to respond to their students needs, particularly, to attend to students with emotional and behavioural disorders. Moreover, Van Reusen, Shoho, and 
Barker (2001) concluded from a study conducted with 125 high school teachers that respondents with more negative attitudes towards inclusion were those who had little knowledge or training in special education. More recent works such as those from Avramidis and Kalyva (2007), and Khochen and Radford (2012) point out the constant demand of teachers to receive appropriate initial and long-term training for inclusion. According to Horne and Timmons (2009), teachers also requested to have more time to coordinate with their colleagues, meet parents, plan their teaching and keep up with all the paperwork derived from having students with SEN in their classes. Teachers also considered they did not have enough material resources and personal supports in their classes (Scruggs and Mastropieri 1996).

Research on teachers' attitudes and perceptions of inclusion conducted in Spain show similar results to those from the international context. Fernández González (1999) surveyed 410 teachers of the province of Vizcaya and found that respondents had positive attitudes towards the philosophy of inclusion but they also showed rejection or indecision regarding its implementation. Similar findings were found in a sample of 115 teachers from the province of Alicante (Cardona 2000). In this study, teachers recognised inclusion as a fundamental right with social benefits for all students, but they were also reluctant to accept the new responsibilities of teaching students with special needs, as they considered the conditions were not appropiate. Further studies have supported this idea (e.g., Alemany and Villuendas 2004; Álvarez et al. 2005) and have pointed out the lack of the adequate training and availability of resources to make inclusion succeed. Jiménez Trens, Díaz Allué, and Carballo (2006) found that a high percentage of teachers think that they do not receive enough training for inclusion $(65.3 \%)$ and $57.8 \%$ feel ill prepared to attend diversity in schools. These teachers also report insufficient time to plan, design adaptations, consult, and collaborate with special education teachers. Finally, teachers in Spain claim more personal support from the educational administration, as well as more material resources to successfully implement inclusion (Alemany and Villuendas 2004).

Other factors such as grade level taught, years of teaching experience and gender have also been examined, but research shows inconclusive results. Some works conclude that secondary education teachers have less positive attitudes towards inclusion than their colleagues from kindergarten and elementary school (Avissar, Reiter, and Leyser 2003), while other studies did not find significant differences between teachers from different grade levels (Avramidis, Bayliss and Burden 2000; 
Scruggs and Mastropieri 1996). Inconclusive results can also be found when the variable gender is taken into account. Some studies state that female teachers are more tolerant towards inclusion than male teachers (Alghazo and Naggar Gaad 2004; Hutzler, Zach, and Gafni 2005), but others (Batsiou et al. 2008; Cardona 2011) found no association between gender and teacher perceptions of inclusion.

In regards to teaching experience, results are inconclusive as well. Parasuram (2006) and Gal, Schreur, and Engel-Yeger (2010) observed that younger teachers and with less years of teaching experience were more favourable towards inclusion than older and more experienced teachers. However, other studies could not prove consistent significant differences between novice and more experienced teachers (Avramidis, Bayliss, and Burden 2000). A more recent study conducted in Spain (Cardona 2011) gave support to those studies that found differences in opinion when teacher experience and grade level taught were taken into account. Results indicated that (a) $86 \%$ of the teachers were in support of inclusion, but inexperienced teachers reported a greater agreement of its benefits than did experienced teachers; (b) only a low percentage of respondents reported that they had the resources (10\%), and the skills (22\%) to appropriately teach SEN students; and (c) 99\% agreed that inclusion requires collaborative planning and teaching, but non-experienced teachers reported significantly greater levels of need of collaboration than experienced did. Kindergarten, elementary, and secondary teachers also differed on their perceptions that inclusion negatively affects the achievement of non-disabled peers $(p<.05)$. Secondary teachers gave support to this opinion more consistently than did kindergarten or elementary school teachers.

Therefore, if schools are to better serve the needs and interests of a growing diverse student population, then teacher needs in regarding the practice of inclusion must be identified. Research on inclusion in Spain has focused mainly on teachers' perceptions and attitudes, considering inclusion in global terms, and little attention has been paid to the factors that may be on the basis of these perceptions and attitudes. An in-depth study using more ample and representative samples of teachers should help increase our knowledge about the specific conditions that hold particular promise to successfully implement inclusion in this country. According to this purpose, the following research questions guided the study:

- Do regular education teachers have positive perceptions of inclusion in Spain? 
- Do these perceptions vary according to grade level taught, teaching experience, and gender?

- Do these teacher beliefs and attitudes vary depending on teacher skills and the availability of time, resources and supports to implement inclusion?

\section{Method}

\section{Participants}

The sample consisted of 336 regular education teachers randomly selected from schools of the province of Alicante, Spain. First, stratified sampling procedures were used, taking the school circumscription (L'Alacantí-Alt/Mitjà Vinalopó, Baix Vinalopó-Baix Segura, Alcoià/Comtat-Les Marines) and the type of school (urban, suburban and rural) as strata to draw a sample of 78 schools which represented $27 \%$ of the schools of the whole province. In a second stage of the sampling procedure, two teachers of each grade level (kindergarten, elementary and secondary education) were randomly selected from the 78 schools selected previously. A total of 109 were male (33\%) and 221 were female $(67 \%)$. Their age ranged between 23 and $64(M=41.5, S D=8.65)$. Sixty-eight of the participants (20.2\%) were teaching kindergarten; 133 (39.6\%), elementary education; and 135 (40.2\%) taught secondary education. Demographic data also showed that 51.3\% ( $n=172)$ had over 15 years of teaching experience; $69(20.6 \%)$ had 9 to 15 years; $55(16.4 \%)$ between 4 and 8 years; and 39 respondents $(11.6 \%)$ had 3 or less years of teaching experience. All participant teachers have at least 1-2 students with SEN included in their class.

Teachers participating in the study were mainly female (90\% in kindergarten, $70 \%$ in elementary, and $53 \%$ in secondary schools), while the number of male teachers was higher in secondary education (47\%) compared to $10 \%$ in kindergarten and $30 \%$ in elementary education. Most of the teachers in kindergarten (94\%) and elementary schools $(91 \%)$ had a bachelor degree, as well as the $60 \%$ of the teaching staff in secondary schools. Thirty six percent of the participant teachers in this grade level had a master degree and only two had a PhD or other degrees (3\%). Regarding years of teaching experience, $37 \%$ of kindergarten teachers had been teaching more than 15 years, so did $69 \%$ of elementary and $42 \%$ of secondary teachers, respectively (see Table $1)$. 
Table 1. Participant teachers' demographic data by grade level

\begin{tabular}{|c|c|c|c|c|c|c|}
\hline & \multicolumn{2}{|c|}{ Kindergarten } & \multicolumn{2}{|c|}{ Elementary } & \multicolumn{2}{|c|}{ Secondary } \\
\hline & $f$ & $\%$ & $f$ & $\%$ & $f$ & $\%$ \\
\hline \multicolumn{7}{|l|}{ Gender } \\
\hline Male & 7 & 10.0 & 39 & 30.0 & 63 & 47.0 \\
\hline Female & 61 & 90.0 & 89 & 70.0 & 71 & 53.0 \\
\hline \multicolumn{7}{|l|}{ Education Degree } \\
\hline Bachelor & 63 & 94.0 & 121 & 91.0 & 81 & 60.0 \\
\hline Master & 4 & 6.0 & 11 & 8.3 & 49 & 36.0 \\
\hline Doctorate & & & & & 2 & 1.5 \\
\hline Other degrees & & & & & 2 & 1.5 \\
\hline No answer & & & 1 & .8 & 1 & 1.0 \\
\hline \multicolumn{7}{|c|}{ Years of teaching experience } \\
\hline $0-3$ & 9 & 13.0 & 11 & 8.0 & 19 & 14.0 \\
\hline $4-8$ & 12 & 18.0 & 9 & 7.0 & 34 & 25.0 \\
\hline $9-15$ & 22 & 32.0 & 22 & 16.0 & 25 & 19.0 \\
\hline+15 & 25 & 37.0 & 91 & 69.0 & 56 & 42.0 \\
\hline
\end{tabular}

\section{Instrumentation}

The Teachers' Perceptions on Inclusion Questionnaire (Cardona, Gómez-Canet, and González-Sánchez 2000) was used to examine teachers' perceptions and perspectives towards inclusion. The instrument consisted of 12 items with statements regarding the process of teaching students with special educational needs in inclusive settings and the conditions under which teachers work (skills, time, resources and supports). The instrument was developed using a five-point Likert scale ( 1 = strongly disagree; $2=$ disagree; 3 = undecided; 4 = agree; 5 = strongly agree). The questionnaire showed an acceptable internal consistency $(\alpha=.69)$ and a good content validity measured by Lawshe's Content Validity Index (1975) with a global CVI of .76.

Construct validity was also examined using an exploratory factor analysis. Principal components analysis revealed the presence of four components with eigenvalues exceeding 1 and explaining 24.2\%, 18.3\%, 9.3\%, and 8.5\% of the variance, respectively. An inspection of the screenplot revealed a clear break after the third component. To help the interpretation of these three components, Varimax rotation was performed. The rotated solution showed the presence of a simple structure with the three components showing strong loadings and all variables loading substantially on only one component (see Table 2). The three-component solution explained a total of $51.89 \%$ of 
the variance with component 1 contributing $21.94 \%$; component 2, 16.90\%; and component 3 , contributing $14.00 \%$. According to this factorial structure, the questionnaire comprised these three factors previously identified that were named respectively: (1) Fundamentals of Inclusion (7 items, $\alpha=.68$ ), (2) Skills and Resources (3 items, $\alpha=.64$ ), and (3) Personal Supports ( 2 items, inter-item correlation $=.63$ ).

Table 2. Structure for items of Teachers' Perceptions towards Inclusion Questionnaire

\begin{tabular}{|c|c|c|c|}
\hline & Factor I & Factor II & Factor III \\
\hline \multicolumn{4}{|l|}{ Fundamentals of Inclusion } \\
\hline I am in favour of inclusion & .783 & & \\
\hline $\begin{array}{l}\text { Inclusion has more advantages than } \\
\text { disadvantages }\end{array}$ & .757 & & \\
\hline $\begin{array}{l}\text { Inclusive education develops tolerance } \\
\text { and respect among students }\end{array}$ & .697 & & \\
\hline $\begin{array}{l}\text { Inclusive education is also possible in } \\
\text { secondary education }\end{array}$ & .645 & & \\
\hline $\begin{array}{l}\text { I think that all students, including those } \\
\text { with moderate and severe disabilities, } \\
\text { can learn in inclusive settings. }\end{array}$ & .463 & & \\
\hline $\begin{array}{l}\text { Inclusion requires the presence in the } \\
\text { classroom of other educators. }\end{array}$ & .418 & & \\
\hline $\begin{array}{l}\text { It is unfair to separate SEN students } \\
\text { from the rest of their peers. }\end{array}$ & .386 & & \\
\hline \multicolumn{4}{|l|}{ Alpha $=.68$} \\
\hline $\begin{array}{l}\text { Training and Resources } \\
\text { I have enough time to teach all my } \\
\text { students. }\end{array}$ & & .743 & \\
\hline $\begin{array}{l}\text { I have enough training to teach all my } \\
\text { students. }\end{array}$ & & .726 & \\
\hline $\begin{array}{l}\text { I have enough material resources to } \\
\text { attend my students' special needs. }\end{array}$ & & .691 & \\
\hline $\begin{array}{l}\text { Alpha }=.64 \\
\text { Variance explained }=16.9 \%\end{array}$ & & & \\
\hline $\begin{array}{l}\text { Personal Supports } \\
\text { I receive enough help from the special } \\
\text { education teacher. }\end{array}$ & & & .850 \\
\hline $\begin{array}{l}\text { I receive enough help from the school } \\
\text { psychologist. }\end{array}$ & & & .795 \\
\hline $\begin{array}{l}\text { Inter-item correlation }=.63 \\
\text { Variance explained }=14 \%\end{array}$ & & & \\
\hline
\end{tabular}




\section{Procedures}

The distribution of the questionnaires was done with the collaboration of the Centres for Training, Innovation and Teaching Resources (CEFIREs) of the province of Alicante which handed out the documents in each of the 78 selected schools. Along with the instruments two cover letters were included, one for the school principal and another one for the teachers participating in the investigation. Both letters pointed out the purpose and relevance of the study, invited teachers to participate and guaranteed the confidentiality of the information provided by the respondents. With the presence of the school principal, participant teachers were selected using simple random sampling procedures. Six teachers were selected in each of the schools (two kindergarten, two elementary, and two secondary school teachers). Only six teachers refused to participate in the study. In that case, another teacher of the same grade level was randomly selected. After the first deadline (two weeks after the surveys were distributed), one member of each of the CEFIREs collected personally all the questionnaires that had already been answered and extended the return date one more week for those who had yet not been responded. The collection by hand facilitated a high response rate of $72 \%$.

\section{Data Analyses}

Descriptive measures were used to examine respondents' attitudes towards inclusion, and their perceptions of skills and time, resources, and supports available to implement inclusion. Parametric measures, such as t-tests for independent samples and one-way between groups analysis of variance (ANOVA) were used to determine differences in teachers' attitudes depending on grade level taught, gender, years of teaching experience, skills, time, resources and supports. A confidence level of $.05(p<.05)$ was used to test the reliability of all estimations (parametric measures and post-hoc tests).

\section{Results}

\section{Teachers' beliefs and perceptions of inclusion}

Overall, respondent's perceptions of inclusion were moderately favourable $(M=3.60$, $S D=.64)$. As it is displayed in Table 3, $84 \%$ of the participants considered that inclusive education favours the development of tolerant and respectful attitudes towards differences. A high percentage of the respondents (65\%) agreed with the principles of inclusion, but still a 35\% disagreed or felt unsure about this issue. Moreover, 59\% thought that it is not fair to separate students with SEN from the rest of their peers and 
also that inclusion has more advantages than disadvantages. However, despite these positive perceptions of the benefits of inclusion, only $40 \%$ of the respondents thought that it is possible to teach students with moderate and severe disabilities in regular classrooms and less than one third (30\%) agreed that inclusion is possible in secondary education. Eighty-one percent of the teachers also considered necessary the presence of personal support in the classroom to better attend diversity.

Participant teachers rated lower inclusion when they were asked about their skills and the availability of time and resources $(M=2.30, S D=.82)$ to put it into practice. In fact, $80 \%$ of the respondents thought they did not have enough material resources to meet their students' special needs, while $69 \%$ of them stated that they did not have sufficient time to teach all their students. Moreover, only $28 \%$ of the participants thought that they had enough skills to address their students' needs. Teachers scored slightly higher regarding personal supports, but still considered they were insufficient $(M=2.86, S D=1.11)$. Thirty-nine percent asserted that the help they received from the special education teacher was not enough and $48 \%$ thought that the support of the school psychologist was insufficient as well.

Table 3. Teachers' attitudes towards inclusion

\begin{tabular}{|c|c|c|c|c|c|c|c|c|}
\hline & \multicolumn{4}{|c|}{ Disagree } & \multicolumn{2}{|c|}{ Unsure } & \multicolumn{2}{|c|}{ Agree } \\
\hline & $M$ & $D T$ & $f$ & $\%$ & $f$ & $\%$ & $f$ & $\%$ \\
\hline \multicolumn{9}{|l|}{ Foundations of Inclusion } \\
\hline $\begin{array}{l}\text { 1. It is unfair to separate students } \\
\text { with SEN from the rest of their } \\
\text { peers. }\end{array}$ & 3.48 & 1.38 & 92 & 27 & 46 & 14 & 197 & 59 \\
\hline $\begin{array}{l}\text { 2. Inclusive education develops } \\
\text { tolerance and respect among } \\
\text { students. }\end{array}$ & 4.20 & .86 & 18 & 5 & 35 & 11 & 181 & 84 \\
\hline $\begin{array}{l}\text { 3. I think that all students, } \\
\text { including those with moderate } \\
\text { and severe disabilities, can learn } \\
\text { in inclusive settings. }\end{array}$ & 3.14 & 1.06 & 93 & 28 & 106 & 32 & 135 & 40 \\
\hline $\begin{array}{l}\text { 4. Inclusive education is also } \\
\text { possible in secondary education. }\end{array}$ & 2.94 & 1.22 & 115 & 36 & 110 & 34 & 96 & 30 \\
\hline $\begin{array}{l}\text { 5. Inclusion has more advantages } \\
\text { than disadvantages. }\end{array}$ & 3.56 & 1.19 & 63 & 19 & 73 & 22 & 198 & 59 \\
\hline 6. I am in favour of inclusion. & 3.78 & .94 & 27 & 8 & 90 & 27 & 215 & 65 \\
\hline $\begin{array}{l}\text { 7. Inclusion requires the } \\
\text { presence in the classroom of } \\
\text { support educators. }\end{array}$ & 4.13 & .01 & 21 & 6 & 41 & 12 & 272 & 82 \\
\hline
\end{tabular}


Total

Skills and Resources

8. I have enough skills to teach all my students.

9. I have enough time to teach all my students.

10. I have enough material resources to attend my students' with special needs.

Total

Personal Supports

11. I receive enough help from the special education teacher.

12. I receive enough help from the school psychologist.

Total $\begin{array}{ll}3.60 & .64\end{array}$

$\begin{array}{llllllll}2.72 & 1.18 & 163 & \mathbf{4 9} & 79 & \mathbf{2 3} & 94 & \mathbf{2 8}\end{array}$

$\begin{array}{llllllll}2.21 & 1.09 & 232 & \mathbf{6 9} & 47 & \mathbf{1 4} & 57 & \mathbf{1 7}\end{array}$

$\begin{array}{llllllll}1.97 & .92 & 268 & \mathbf{8 0} & 40 & \mathbf{1 2} & 28 & \mathbf{8}\end{array}$

$2.30 \quad .82$

$\begin{array}{llllllll}2.97 & 1.25 & 129 & \mathbf{3 9} & 57 & \mathbf{1 8} & 140 & \mathbf{4 3}\end{array}$

$\begin{array}{llllllll}2.76 & 1.22 & 159 & \mathbf{4 8} & 61 & \mathbf{1 8} & 112 & \mathbf{3 4}\end{array}$

$2.86 \quad 1.11$

Differences in teachers' perceptions of inclusion as a function of grade level taught, years of teaching experience, and gender

T-tests for independent samples and a series of ANOVAs were conducted to examine differences in teachers' perceptions of inclusion taking into account grade level taught, years of teaching experience, and gender. Statistically significant differences were found regarding grade level taught (Table 4). Scheffé post-hoc tests showed that kindergarten educators $(M=4.40, S D=.67)$ agreed more than secondary teachers $(M=$ $4.06, S D=.91)$ that inclusion favours the development of students' tolerant and respectful attitudes towards diversity $[F(2,331)=3.73, p=.025]$. Despite low scores in all grade levels, kindergarten and elementary school teachers also perceived that they have more time $(M=2.41$ and 2.31$)$ and resources $(M=2.09$ and 2.06) to address students' special educational needs than secondary school teachers $(M=2.01$ and 1.81 , respectively). No statistically significant differences were found when considering teaching experience and gender. 
Table 4. Teachers' perceptions of inclusion based on grade level taught

\begin{tabular}{|c|c|c|c|c|c|c|c|c|c|c|}
\hline & Kind & arten & Elem & ntary & Seco & dary & & & & \\
\hline $\begin{array}{l}\text { Foundations of } \\
\text { Inclusion }\end{array}$ & $M$ & $S D$ & $M$ & $S D$ & $M$ & $S D$ & $\boldsymbol{F}$ & $d f$ & $p$ & Dir. \\
\hline $\begin{array}{l}\text { 1. It is unfair to separate } \\
\text { students with SEN from } \\
\text { the rest of their peers. }\end{array}$ & 3.51 & 1.46 & 3.64 & 1.40 & 3.31 & 1.31 & 1.88 & 2 & .154 & \\
\hline $\begin{array}{l}\text { 2. I am in favour of } \\
\text { inclusion. }\end{array}$ & 3.88 & .91 & 3.78 & .98 & 3.74 & .92 & .50 & 2 & .606 & \\
\hline $\begin{array}{l}\text { 3. Inclusive education } \\
\text { develops tolerance and } \\
\text { respect among students. }\end{array}$ & 4.40 & .67 & 4.24 & .88 & 4.06 & .91 & 3.73 & 2 & $.025 *$ & $\mathrm{~K}>\mathrm{S}$ \\
\hline $\begin{array}{l}\text { 4. I think that all } \\
\text { students, including } \\
\text { those with moderate } \\
\text { and severe disabilities, } \\
\text { can learn in inclusive } \\
\text { settings. }\end{array}$ & 3.10 & 1.12 & 3.18 & 1.06 & 3.11 & 1.04 & .18 & 2 & .829 & \\
\hline $\begin{array}{l}\text { 5. Inclusion requires the } \\
\text { presence in the } \\
\text { classroom of support } \\
\text { educators. }\end{array}$ & 4.18 & .99 & 4.13 & .96 & 4.10 & .843 & .13 & 2 & .872 & \\
\hline $\begin{array}{l}\text { 6. Inclusion has more } \\
\text { advantages than } \\
\text { disadvantages. }\end{array}$ & 3.78 & .94 & 3.56 & 1.22 & 3.44 & 1.26 & $\begin{array}{c}1.79 \\
7\end{array}$ & 2 & .167 & \\
\hline $\begin{array}{l}\text { 7. Inclusive education is } \\
\text { also possible in } \\
\text { secondary education. }\end{array}$ & 3.00 & 1.05 & 2.92 & 1.34 & 2.93 & 1.19 & .09 & 2 & .906 & \\
\hline \multicolumn{11}{|l|}{ Skills and Resources } \\
\hline $\begin{array}{l}\text { 8. I have enough skills } \\
\text { to teach all my students. }\end{array}$ & 2.50 & 1.05 & 2.99 & 1.19 & 2.56 & 1.18 & 6.08 & 2 & $.003 * *$ & $E>K, S$ \\
\hline $\begin{array}{l}\text { 9. I have enough time to } \\
\text { teach all my students. }\end{array}$ & 2.41 & 1.09 & 2.31 & 1.10 & 2.01 & 1.06 & 3.87 & 2 & $.022 *$ & $\mathrm{~K}>\mathrm{S}$ \\
\hline $\begin{array}{l}10 . \text { I have enough } \\
\text { resources to attend my } \\
\text { students' special needs. }\end{array}$ & 2.09 & .85 & 2.06 & .95 & 1.81 & .92 & 3.10 & 2 & $.046 *$ & $\mathrm{~K}, \mathrm{E}>\mathrm{S}$ \\
\hline \multicolumn{11}{|l|}{ Personal Supports } \\
\hline $\begin{array}{l}\text { 11. I receive enough } \\
\text { help from the special } \\
\text { education teacher. }\end{array}$ & 2.82 & 1.07 & 3.12 & 1.30 & 2.89 & 1.26 & 1.64 & 2 & .195 & \\
\hline $\begin{array}{l}\text { 12. I receive enough } \\
\text { help from the school } \\
\text { psychologist. }\end{array}$ & 2.63 & 1.15 & 2.78 & 1.26 & 2.80 & 1.21 & .44 & 2 & .638 & \\
\hline
\end{tabular}




\section{Differences in beliefs and attitudes towards inclusion depending on teacher skills, resources and supports}

Teachers' beliefs on the foundations of inclusion did not vary significantly as a function of teacher skills and the availability of time and material resources to implement inclusion. Neither teachers' skills nor the time and resources they have to meet students' needs seem to affect their beliefs about inclusion. Nevertheless, these beliefs do vary depending on the availability of personal supports. Statistically significant differences were found at the level of $p<.05[F(2,298)=4.16, p=.016]$. Teachers who considered they received enough help from the special education teacher reported more favourable beliefs and attitudes on inclusion $(M=26.01, S D=4.21)$ than those who thought this support was insufficient $(M=24.66, S D=4.68)$ or neither sufficient nor insufficient $(M$ $=24.21, S D=4.79)$. Results are displayed in Table 5 .

Table 5. Teachers' beliefs and attitudes towards inclusion based on teacher perceptions of skills, time, resources and supports

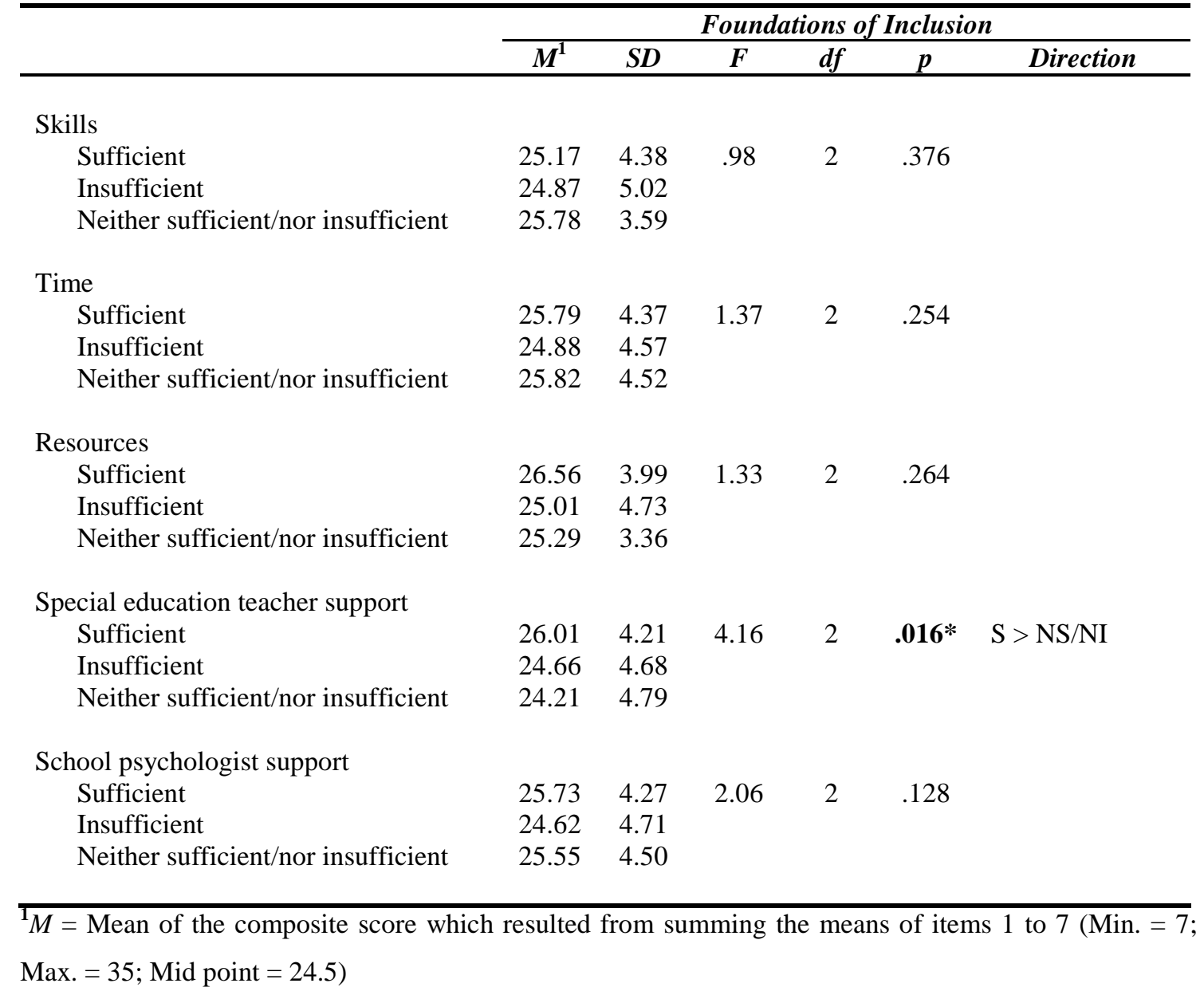




\section{Discussion}

The purpose of this study was to examine teachers' perceptions of inclusive education and to determine to what extent these perceptions may be affected by grade level taught, teaching experience, gender, skills and the availability of material resources and personal supports. The investigation depicts the conditions under which inclusion is currently being implemented in Spain and helps to inform areas of need and improvement for in-service teacher education programmes, as well as for teacher education reform. The study contributes to confirm that teachers from this region of Spain generally accept the principles of inclusion but definitely perceive they have insufficient skills, material resources, and personal supports to implement this policy in a meaningful and responsible way. Therefore, it provides valuable information for government and non-government agencies that work on the implementation of this policy. Results, however, should be considered cautiously. First, findings only represent the opinion on inclusion of regular education teachers from the province of Alicante and may not reflect the perceptions of other teachers from different provinces or regions in Spain. Second, are not totally free of socially desirable responses.

\section{Teachers' perceptions of inclusion}

Overall, teachers from the province of Alicante agreed with the concept of inclusion. They think that teaching all students in regular classes, including those with special needs, have more advantages than disadvantages and that this practice favours the development of tolerance and respect among students. They also considered that it is unfair to separate students with SEN from the rest of their peers. However, they were reluctant to include students with moderate and severe disabilities in regular classes and thought of inclusion as difficult to achieve in secondary education. To manage inclusion in a responsible way they also considered that other professionals (e.g., special education teachers and school psychologists) should help regular education teachers in their work. These findings are consistent with previous research (Alemany and Villuendas 2004; Álvarez et al. 2005; Avramidis and Norwich 2002; Cook, Cameron, and Tankersley 2007; Scruggs and Mastropieri 1996) that shows that teachers support inclusion and are willing to include students with special needs in their classrooms. However, in line with these previous studies results also showed that teachers' acceptance of inclusion decreased when the conditions under which inclusion is being implemented are not favourable (e.g., lack of time, and supports). 
Some of the barriers that have been identified in this study as obstacles that may prevent teachers' acceptance of inclusion in a more responsible way appear to be beyond the classroom level. Specifically, these obstacles relate to teacher skills, resources and supports. Findings revealed that respondents perceived they did not have enough preparedness nor sufficient time, material resources, and personal supports to adequately meet their students' special needs. They felt ill prepared to teach all their students in class and thought that they did not have enough tools and supports to face the new demands of inclusion. This finding supports those from Khochen and Radford (2012), Horne and Timmons (2009), and Idol (2006) that suggest that teachers consider that the pre-service and in-service training they received was not enough to address diversity in their classes. This is not surprising given that higher education programmes in education and in-service training do not emphasise the preparation of general education teachers for working with the diversity of students that currently constitute general education classrooms. Teacher education programmes in Spain currently prepare teachers for initial certification in three majors (Kindergarten, Elementary, and Secondary Education). Kindergarten and elementary teacher training programmes already include compulsory courses on diversity, but secondary teachers end their programmes with no courses on inclusive education. A review of pre-service teacher training programmes offered by 16 universities in this country (Cardona et al. 2004), highlighted the relative small number of courses in inclusive education. Of the total number of programmes reviewed, only $25 \%$ included either a compulsory or an elective course in special/inclusive education.

The request of more time, resources, and training has been a constant in the research literature on inclusion. All of these limitations can be problematic because the lack of adequate conditions for inclusion may be hindering the quality of education teachers provide to students with SEN and, ultimately, teacher willingness to put inclusion into practice despite their positive attitudes towards it. However, some experiences in developing countries (e.g., India), have shown that even with little resources inclusive education is also possible (Alur 2007). Sometimes the necessity of teaching all students in one classroom or school because there are no other special services, helps to develop new practices (eg., community collaboration, organisational changes, etc.) that promote the participation and learning of every student. 


\section{Teachers' perceptions as a function of grade level taught, teaching experience and gender}

Significant differences in teachers' perceptions relative to inclusion were found when analysed as a function of grade level taught. Findings showed that kindergarten and elementary teachers had more favourable perceptions and attitudes towards inclusion than secondary school teachers. These results support those of Cardona (2011), and Avissar, Reiter, and Leyser (2003) that state that teachers of higher education levels show less positive attitudes towards inclusive education than teachers of lower levels. As Schumm and Vaughn (1992) noted, numerous middle and high school teachers are unaware when they have a mainstream learner in class and rarely use individualised educational programmes in their planning. Moreover, these teachers are well trained in specific subjects (e.g., Mathematics, History and Science) but they lack specific knowledge to teach and, especially, address students' special educational needs. As we said before, in Spain, while kindergarten and elementary school teachers receive at least 12 credits on diversity, secondary education teachers only receive a 6 credit course. Furthermore, secondary school teachers usually have more pressure to achieve the subject goals at the end of the school year than their colleagues from kindergarten and elementary school, leaving aside the attention to diversity in order to accomplish those goals. Therefore, pre-service and in-service programmes should be developed to help secondary education teachers to learn more about the education of SEN students and the way to address students' learning needs. A better understanding of students' individual differences and their learning styles will keep teachers from developing prejudices towards them and will help promote a better acceptance of inclusion.

Respondents' perceptions of inclusion did not differ significantly based on years of teaching experience and gender. Comparing to other studies, inconsistent results can be found in these areas of interest. While studies by Avramidis and Norwich (2002) and Batsiou et al. (2008) suggest that neither the gender nor the teaching experience, are strong predictors of teachers' attitudes towards inclusion, Cardona (2011), in a study carried out in Spain, found that inexperienced teachers reported a greater agreement of the benefits of inclusion than did experienced teachers, as well as significantly greater levels of need of collaboration which is one of the requirements for a successful inclusion. 


\section{Influence of skills, and availability of time, resources, and supports on teachers'}

\section{beliefs and attitudes towards inclusion}

Although respondents in this study perceived not good conditions to include efficiently students with SEN in their classrooms (only 8\% reported they had the resources, $28 \%$ the skills, and 17\% the time to appropriately teach their SEN students), such as conditions did not seem to affect teachers' beliefs on the foundations of inclusion. So did, however, the availability of personal supports. Results showed that teachers that perceived they had enough support from the special education teacher they also had more favourable beliefs and attitudes towards inclusion than teachers without enough support. Similar findings were reported in previous research (Avramidis, Bayliss, and Burden 2000; Cardona 2011; Coutsocostas and Alborz 2010) suggesting that the scarcity of personal supports may prevent teachers to promote inclusion and develop positive attitudes. As Avramidis and Kalyva (2007) pointed out, teachers do not seem to have unfavourable attitudes towards inclusion; they simply do not find the solutions to respond to problems they consider that are out of their control. Governments and educational administrations should pay more attention to these issues and provide teachers with all the supports and resources necessary to make inclusion work avoiding then teachers' discouragement and contradictions in regarding this educational practice.

\section{Conclusion}

Spain is considered to be one of the most inclusive countries in Europe with a progressive legislation that guarantee the full inclusion of students with SEN into regular schools and classrooms. The results of this study showed contradicting perceptions toward the practice of inclusion. On one side, a majority of respondents were in support of the philosophy of inclusion. On the other, only a low percentage of respondents reported they have the adequate conditions (skills, time, and resources) to appropriately handle the needs of students with SEN in their classrooms. This is problematic because of the confusions it generates and the negative academic consequences for the students with special educational needs. The study clearly shows that teachers with less favourable perceptions of inclusion are those with insufficient skills, resources, supports. Therefore, in light of these results, educational administrations and proponents of inclusion should definitely improve the conditions under which inclusion is being implemented in this Spanish region making available to schools and teachers the supports and resources needed to make them more comfortable 
with the practice of inclusion. In addition, more specific and substantive teacher inservice and pre-service training on inclusion should be provided, especially to secondary education teachers. Inclusion is a shared responsibility, therefore, the identified barriers that currently prevent a more successful implementation of this practice have to be necessarily reduced and progressively eliminated. Future studies should be carried out at national level using more ample and representative regions but at the same time designed to capture through interviews, discussion groups, or observation the authentic motives that could explain the ambivalent and contradicting teacher perceptions of inclusive education.

\section{Notes on contributors}

Dr. Esther Chiner-Sanz is a lecturer of Special and Inclusive Education at the Faculty of Education, University of Alicante, Spain.

Dr. M. Cristina Cardona-Moltó is a professor of Special and Inclusive Education at the Faculty of Education, University of Alicante, Spain.

\section{References}

Alemany, I., and M.D. Villuendas. 2004. Las actitudes del profesorado hacia el alumnado con necesidades educativas especiales. Convergencia. Revista de Ciencias Sociales 11: 183-215.

Alghazo, E.M., and E.E. Naggar Gaad. 2004. General education teachers in the United Arab Emirates and their acceptance of the inclusion of students with disabilities. British Journal of Special Education 31: 94-9.

Alur, M. 2007. The lethargy of a nation: Inclusive education in India and developing systemic strategies for change. In Policy, Experience and Change: Crosscultural reflections on inclusive education, ed. L. Barton and F. Armstrong, 91108. Dordrecht: Springer.

Álvarez, M., P. Castro, M.A. Campo, and E. Álvarez. 2005. Actitudes de los maestros ante las necesidades educativas específicas. Psicothema 17, no. 4: 601-6.

Avissar, G., S. Reiter, and Y. Leyser. 2003. Principals' views and practices regarding inclusion: The case of Israeli elementary school principals. European Journal of Special Needs Education 18: 355-69. 
Avramidis, E., and B. Norwich. 2002. Teachers' attitudes towards integration/inclusion: a review of the literature. European Journal of Special Needs Education 17, no. 2: $129-47$.

Avramidis, E., and E. Kalyva. 2007. The influence of teaching experience and professional development on Greek teachers' attitudes towards inclusion. European Journal of Special Needs Education 22, no. 4: 367-89.

Avramidis, E., P. Bayliss, and R. Burden. 2000. A survey into mainstream teachers' attitudes towards the inclusion of children with special educational needs in the ordinary school in one local education authority. Educational Psychology 20, no. 2: 191-211.

Batsiou, S., E. Bebetsos, P. Panteli, and P. Antoniou. 2008. Attitudes and intention of Greek and Cypriot primary education teachers towards teaching pupils with special educational needs in mainstream schools. International Journal of Inclusive Education 12, no. 2: 201-19.

Cardona, M.C. 2000. Regular classroom teachers' perceptions of inclusion: implication for teachers' preparation programs in Spain. In Educational research in Europe, ed. D. Day, and D. Veen, 37-47. Leuven: Garant \& European Eduational Research Association.

Cardona, M.C. 2009. Current trends in special education in Spain: Do they reflect legislative mandates of inclusion? The Journal of the International Association of Special Education 10, no. 1: 4-10.

Cardona, M.C. 2011. Teachers' opinion relative to inclusion in Spain: a comparison between experienced and inexperienced teachers. The International Journal of Diversity in Organizations, Communities, and Nations 11, no. 3: 151-168.

Cardona, M.C., E. Chiner, P. Gómez-Canet, M.E. González-Sánchez, and A. Lattur. 2004. La educación especial en los futuros estudios de máster en psicopedagogía: Diseño de una guía docente. In Investigar el Espacio Europeo de Educación Superior, ed. J.G. Bernabeu-Pastor, and N. Sauleda, 1-26. Alicante: Vicerrectorado de Convergencia Europea y Calidad-ICE de la Universidad de Alicante. 
Cardona, M.C., P.F. Gómez-Canet, and M.E. González-Sánchez. 2000. Cuestionario de Percepciones del Profesor acerca de la Pedagogía Inclusiva. Alicante: Universidad de Alicante.

Cook, B.G., D.L. Cameron, and M. Tankersley. 2007. Inclusive teachers' attitudinal ratings of their students with disabilities. The Journal of Special Education 40, no. 4: 230-8.

Coutsocostas, G-G., and A. Alborz. 2010. Greek mainstream secondary school teachers' perceptions of inclusive education and of having pupils with complex learning disabilities in the classroom/school. European Journal of Special Needs Education 25, no. 2: 149-64.

Echeita, G. and M.A. Verdugo. 2004. Diez años después de la Declaración de Salamanca sobre Necesidades Educativas Especiales en España. Entre la retórica esperanzadora y las resistencias al cambio. In La Declaración de Salamanca sobre necesidades educativas especiales 10 años después. Valoración y prospectiva, ed. G. Echeita, and M.A. Verdugo, 209-16. Salamanca, Spain: INICO, Universidad de Salamanca.

European Agency for Development in Special Needs Education (EADSNE). 2003. Special education across Europe in 2003. Trends in provision in 18 European countries. Brussels: EADSNE.

European Agency for Development in Special Needs Education (EADSNE). 2011. Mapping the implementation of policy for inclusive education: An exploration of challenges and opportunities for developing indicators. Odense, Denmark: EADSNE.

Evans, J.L. 1998. Inclusive ECCD: A fair start for all children. Coordinators' Notebook: An International Resource for Early Childhood Development 22: 123.

Fernández González, A. 1999. Estudio de las actitudes del profesorado de los centros ordinarios de Vizcaya hacia la integración escolar. Paper presented at the III Jornadas Científicas de Investigación sobre Personas con Discapacidad dentro del Simposio Retos en la respuesta al retraso mental en la vida adulta: Formación, oportunidades y calidad de vida, March 19, in Salamanca, Spain.

Gal, E., N. Schreur, and B. Engel-Yeger. 2010. Inclusion of children with disabilities: teachers' attitudes and requirements for enviromental accommodations. International Journal of Special Education 25, no. 2: 89-99. 
Hegarty, S. 1998. La educación especial en Europa. Revista Española de Pedagogía 204: 345-359.

Horne, P.E., and V. Timmons. 2009. Making it work: teachers' perspectives on inclusion. International Journal of Inclusive Education 13, no. 3: 273-86.

Hutzler, Y., S. Zach, and O. Gafni. 2005. Physical education students' attitudes and self-efficacy towards the participation of children with special needs in regular classes. European Journal of Special Needs Education 20, no. 3: 309-27.

Idol, L. 2006. Toward inclusion of special education students in general education. A program evaluation of eight schools. Remedial and Special Education 27, no. 2: 77-94.

Jiménez Trens, M.A., M.T. Díaz Allué, and R. Carballo. 2006. Respuesta educativa a la diversidad desde la perspectiva del profesorado de la ESO: Estudio en la Comunidad Autónoma de La Rioja. Contextos Educativos 8-9: 33-50.

Khochen, M., and J. Radford. 2012. Attitudes of teachers and heateachers towards inclusion in Lebanon. International Journal of Inclusive Education 16, no. 2: 139-53.

Lawshe, C.H. 1975. A quantitative approach to content validity. Personnel Psychology 28: 563-75.

LGE. 1970. Ley 14/1970, de 4 de agosto, general de educación y financiamiento de la reforma educativa. Boletín Oficial del Estado, 06/08/1970.

LISMI. 1982. Ley 13/1982, de 7 de abril, de Integración Social de los Minusválidos. Boletín Oficial del Estado, 20/04/1982.

LOCE. 2002. Ley Orgánica 10/2002, de 23 de diciembre, de Calidad de la Educación. Boletín Oficial del Estado, 24/12/2002.

LOE. 2006. Ley Orgánica 2/2006, de 3 de mayo, de Educación. Boletín Oficial del Estado, 04/05/2006.

LOGSE. 1990. Ley 1/1990, de 3 de octubre, de Ordenación General del Sistema Educativo. Boletín Oficial del Estado, 04/10/1990.

Parasuram, K. 2006. Variables that affect teachers' attitudes towards disability and inclusive education in Mumbai, India. Disability and Society 21: 231-42.

Schumm, J. S., and S. Vaughn. 1992. Planning for mainstreamed special education students: Perceptions of general classroom teachers. Exceptionality 3, no. 2: 8198. 
Scruggs, T.E., and M.A. Mastropieri. 1996. Teacher perceptions of mainstreaming/inclusion, 1958-1995: a research synthesis. Exceptional Children 63, no. 1: 59-74.

UNESCO. 1994. The Salamanca Statement and framework for action on special needs education. Paris: UNESCO

Van Reusen, A.K., A.R. Shoho, and K.S. Barker. 2001. High school teacher attitudes toward inclusion. The High School Journal 84, no. 2: 7-17. 